\title{
Abrogation of immune complex glomerulonephritis by native carboxypeptidase and pharmacological antagonism of the $\mathrm{C} 5 \mathrm{a}$ receptor
}

\author{
Jessy J. Alexander ${ }^{1}$, Lee D. Chaves ${ }^{1}$, Anthony Chang ${ }^{2}$, Shruti Dighe ${ }^{1}$, Alexander Jacob ${ }^{1}$ \\ and Richard J. Quigg ${ }^{1}$
}

Activation of complement generates $\mathrm{C} 5 \mathrm{a}$ which leads to signaling through $\mathrm{C} 5 \mathrm{aR} 1$. This is tightly controlled, including by the plasma proteins factor $\mathrm{H}(\mathrm{FH})$ and carboxypeptidase N. Here we studied a chronic serum sickness (CSS) model of glomerulonephritis (GN) in which there is an active humoral immune response, formation of glomerular immune complexes (ICs), and resulting glomerular inflammation. The antibody response, glomerular IC deposition, the degree of $\mathrm{GN}$, and consequent renal functional insufficiency in CSS were all worse in $\mathrm{FH}-/-$ mice compared to wild-type $\mathrm{FH}+/+$ animals. This was ameliorated in the former by giving a C5aR 1 antagonist for the final 3 weeks of the 5-week protocol. In contrast, blocking CP-mediated inactivation of $\mathrm{C} 5 \mathrm{a}$ increased these disease measures. Thus, complement regulation by both plasma $\mathrm{FH}$ and $\mathrm{CP}$ to limit the quantity of active $\mathrm{C} 5 \mathrm{a}$ is important in conditions where the humoral immune response is directed to a continuously present foreign antigen. Signaling through C5aR 1 enhances the humoral immune response as well as the inflammatory response to ICs that have formed in glomeruli. Both effects are relevant even after disease has begun. Thus, pharmacological targeting of C5a in IC-mediated GN has potential clinical relevance.

Cellular \& Molecular Immunology (2016) 13,651-657;doi:10.1038/cmi.2015.45; published online 13 July 2015

Keywords: $\mathrm{C} 5 \mathrm{a}$; carboxypeptidase $\mathrm{N}$; factor $\mathrm{H}$; glomerulonephritis

\section{INTRODUCTION}

The complement system provides a first line of defense against some microorganisms and participates in innate and adaptive immune responses to many others. More than 30 plasma and cell-associated proteins in three activation pathways converge on C3 and C5 to generate C3a, C3b, C5a, and C5b-9, each of which has biological activity. The receptors (R) for C3a and $\mathrm{C} 5 \mathrm{a}$ are rhodopsin-like class A peptide $\mathrm{G}$ protein-coupled sevenspan transmembrane Rs. The three extracellular loops of C3aR and C5aR1 confer ligand binding specificity while their activation is transduced through various $\alpha \beta \gamma$ G-proteins at the internal portion of the plasma membrane ${ }^{1,2}$. While traditionally considered pro-inflammatory on BM-derived cells, it is clear that C3aR and C5aR1 have a more widespread distribution with a variety of effects attributable to their activation ${ }^{3-5}$.

As it developed, the adaptive immune system incorporated the complement system, conferring C3/C5-binding proteins to lymphocytes and dendritic cells. For example, the B lymphocyte signaling complex contains complement receptor 2 , which can be activated by immune complexes (ICs) containing natural antibody, foreign antigen, and activated C3, which then facilitates adaptive humoral responses to that antigen $^{6}$. More recent evidence has shown an important role for complement in cellular immunity. Here, it appears the T cell and its antigen-presenting dendritic cell partner generate complement activation products, with signals through C3aR and/or C5aR1 affecting T cell proliferation and differentiation in normal $\mathrm{T}$ cell responses, as well as in autoimmunity and alloimmunity $^{7-11}$.

Productive complement activation could be considered as the successful generation of biologically active $\mathrm{C} 3$ and $\mathrm{C} 5$ products. For this to occur, the system must overcome several obstacles, not the least of which is time and space; that is, many of the biologically active intermediates have a very short period

${ }^{1}$ Division of Nephrology, Department of Medicine, University at Buffalo School of Medicine and Health Sciences, Buffalo, NY, USA and ${ }^{2}$ Department of Pathology, The University of Chicago, Chicago, IL, USA

Correspondence: Dr Jessy J. Alexander, Division of Nephrology, State University of New York at Buffalo, Clinical and Translational Research Center, 875 Ellicott Street, 8-022, Buffalo, NY 14203, USA

E-mail: jessyale@buffalo.edu

Received: 17 March 2015; Revised: 27 April 2015; Accepted: 27 April 2015 
of time to find the next protein partner in sequence or suffer the fate of inactivation. There are also a host of complement regulatory proteins acting throughout the pathways. Spontaneous alternative pathway activation in the fluid phase is regulated by complement factor $\mathrm{H}(\mathrm{FH})$. The zinc metalloproteinase, carboxypeptidase $\mathrm{N}(\mathrm{CPN})$, is released into serum as an active enzyme, where it potently deactivates $\mathrm{C} 3 \mathrm{a}$ and $\mathrm{C} 5 \mathrm{a}$ by removing their C-terminal arginine residues ${ }^{12}$. Carboxypeptidase B2 is present in plasma as a thrombin-activatable proenzyme, which can also cleave $\mathrm{C} 3 \mathrm{a}$ and $\mathrm{C}^{2} \mathrm{a}^{13,14}$. The phosphatidylinositollinked CPM is present in the kidney among other organs ${ }^{15,16}$, where it potentially could also deactivate C3a and C5a.

Induction of chronic serum sickness (CSS) leads to deposition of ICs in glomeruli ${ }^{17}$. Despite the substantial accumulation of ICs containing iC $3 \mathrm{~b}$ and IgG Fc (i.e., ligands for $\beta 2$ integrins and $\mathrm{Fc} \gamma \mathrm{Rs}$ ) wild-type $\mathrm{C} 57 \mathrm{BL} / 6$ mice have little glomerular inflammation in $\mathrm{CSS}^{18}$. In contrast, $\mathrm{FH}$-deficient mice with CSS uniformly develop diffuse proliferative glomerulonephritis (GN) within 5 weeks ${ }^{18-20}$. The GN in CSS is characterized by endocapillary inflammation, including with $\mathrm{F} 4 / 80^{+}$ macrophages around sites of $\mathrm{ICs}^{21}$. The relevance for complement receptors in this model is $\mathrm{C} 5 \mathrm{aR} 1^{-1-} \mathrm{FH}^{-1-}$ mice with CSS do not develop $\mathrm{GN}^{21}$ while $\mathrm{Cd}_{11} 1 \mathrm{~b}^{-/-} \mathrm{FH}^{-1-}$ mice have exacerbated features of $\mathrm{GN}^{22}$.

In studies using gene-targeted mice, the significant effects of $\mathrm{C} 5 \mathrm{aR} 1$ on the immune response could not be separated from those in inflammation. Here we attempted to surmount this by administering a cyclic peptide antagonist (ant) of C5aR1 (PMX53, (Ac)Phe-[Orn-Pro-DCha-Trp-Arg] $)^{23-25}$ beginning 2 weeks after the start of active immunization of $\mathrm{FH}^{-1-}$ mice. Our hypothesis was effects of C5aR1 on the immune response occur in the induction phase but become insignificant in maintaining humoral immunity. We also evaluated the role for C5aR inactivation by $\mathrm{CP}$, through the use of the potent $\mathrm{CP}$ inhibitor (inh), DL-2-mercaptomethyl-3-guanidinoethylthiopropanoic acid $\left(\mathrm{K}_{\mathrm{i}} \sim 2 \times 10^{-9} \mathrm{M}\right)^{26,27}$. These data show the importance of $\mathrm{C} 5 \mathrm{a}$ in generating and perpetuating a humoral immune response in CSS, and the resultant IC-mediated GN.

\section{MATERIALS AND METHODS}

\section{Experimental animals}

Normal wild-type C57BL/6 mice were from Jackson Laboratories. The $\mathrm{FH}^{-1-}$ mouse strain was generated and kindly provided by Drs Matthew Pickering and Marina Botto (Imperial College of London ${ }^{28}$ and continuously backcrossed onto the C57BL/6 strain in our laboratory over 10 years. Genotyping within and around FH alleles was performed using PCR-based approaches. All studies were approved by the University of Chicago and University at Buffalo Institutional Animal Care and Use Committees.

\section{CSS protocol}

CSS was induced in male $\mathrm{FH}^{-1-}$ or wild-type mice between the ages of 6-8 weeks with daily intraperitoneal administration of 4 $\mathrm{mg}$ horse spleen apoferritin (Calzyme Laboratories) ${ }^{17,18,29-31}$. Littermate controls received intraperitoneal injections of saline vehicle contemporaneously.
C5aR1 ant (PMX53, (Ac)Phe-[Orn-Pro-DCha-Trp-Arg], kindly provided by $\mathrm{Dr}$ John Lambris, University of Pennsylvania) was delivered at a dose of $25 \mu \mathrm{g}$ /day via a mini-osmotic pump (Alzet) a regimen effective in our prior studies in lupus mice ${ }^{25}$. This was started 2 weeks after immunization with apoferritin had begun, at which time clinically evident disease features were present (unpublished data). The mini-osmotic pump was changed weekly. To control for peptide administration delivered via mini-osmotic pumps, a cohort of $\mathrm{FH}^{-1-}$ mice $(n=4)$ immunized with apoferritin received scrambled peptide on the same schedule. This did not affect disease features (BUN, GN scores) compared to $\mathrm{FH}^{-/-}$ mice with CSS $(n=13)$ not given peptide. As such, these data were pooled. $C P_{\text {inh }}$ (Plummer's reagent, DL-2-mercaptomethyl-3-guanidinoethylthiopropanoic acid, Calbiochem) was administered intraperitoneally at a dose of $1 \mathrm{mg}$ every 12 hours $^{27}$ starting 3 weeks after the start of daily apoferritin administration. After 5 weeks, animals were euthanized, and blood and tissues collected.

\section{Measurements from serum}

Blood urea nitrogen (BUN) concentrations were determined with a Beckman Autoanalyzer. Anti-apoferritin IgG was measured by ELISA. Polystyrene plates were coated with $5 \mu \mathrm{g} / \mathrm{ml}$ of apoferritin. After blocking with $1 \%(\mathrm{wt} / \mathrm{vol})$ bovine serum albumin, plates were incubated with serial dilutions of serum samples or anti-horse ferritin (Jackson ImmunoResearch), followed by horseradish peroxidase-conjugated anti-mouse IgG (Kirkegaard and Perry Laboratories), and o-Phenylenediamine peroxidase substrate (Sigma-Aldrich). The data were presented as arbitrary units relative to a standard curve generated with anti-horse ferritin.

\section{Measurements from renal tissue}

Tissues were fixed in $10 \%$ buffered formalin and embedded in paraffin, from which $4 \mu \mathrm{m}$ thick sections were cut and stained with periodic acid-Schiff. Slides were scored in a blinded manner by a renal pathologist (AC) for the extent of GN on a scale of 0 to 4 (in increments of 0.5 ) according to the schema of Passwell et al. ${ }^{32}$ as described previously ${ }^{18,19}$.

About $4 \mu \mathrm{m}$ sections from frozen mouse kidneys were fixed in ethanol:ether (1:1) for 10 minutes followed by $95 \%$ ethanol for 20 minutes, washed with PBS and stained with fluoresceinanti-mouse C3 and rhodamine-anti-mouse IgG (Cappel, MP Biomedicals). Slides were viewed with an Olympus BX-60 IF microscope. Representative photomicrographs were taken at identical settings with a Hamamatsu EM-CCD camera. Merged images were generated with NIH Image J software.

\section{Statistics}

Data were analyzed using Minitab statistical software (v. 16, College Park, MD, USA). Data sets were first analyzed with the Anderson-Darling normality test and considered parametric with $\mathrm{H} \alpha>0.05$. Parametric and non-parametric data are presented as mean \pm SEM and median (Q1-Q3), respectively. All data presented graphically are from individual animals. 
Parametric data were analyzed by one-way ANOVA with comparisons among groups using Tukey's method. Non-parametric data sets were analyzed comparably by Kruskal-Wallis and Mood's Median testing. Potential correlations among variables were first examined by calculating the Pearson product moment; those significant were further examined using the least-squares method.

\section{RESULTS}

\section{Contrasting effects of inhibiting C5aR1 and CP on ICGN}

We generated CSS by actively immunizing C57BL/6 $\mathrm{FH}^{-1-}$ mice with a daily intraperitoneal dose of $4 \mathrm{mg}$ horse spleen apoferritin $(n=36)$. As controls, $\mathrm{FH}^{-/-}$mice were treated identically, except apoferritin was omitted from the injections $(n=13)$. After 2 weeks of apoferritin administration, some mice received C5aR1 ant $(n=7), \mathrm{CP}_{\text {inh }}(n=8)$, or both $(n=4)$ until the conclusion of the study after 5 weeks of apoferritin or saline administration.

As shown in Figure 1, control $\mathrm{FH}^{-1-}$ mice had normal renal function at the end of the 5-week experimental protocol as assessed by BUN levels of $27.9 \pm 1.1 \mathrm{mg} / \mathrm{dl}$. In contrast, $\mathrm{FH}^{-1-}$ mice with CSS induced by repetitive apoferritin immunization had impaired renal function (BUN $=37.0 \pm$ $2.2 \mathrm{mg} / \mathrm{dl}$ ). This was also true of those mice receiving $\mathrm{CP}_{\text {ant }}$ (BUN $=39.7 \pm 2.8 \mathrm{mg} / \mathrm{dl})$. Renal insufficiency was prevented in $\mathrm{FH}^{-/-}$mice receiving $\mathrm{C} 5 \mathrm{aR} 1_{\text {ant }}$ for the final 3-week period, whether or not $\mathrm{CP}_{\text {inh }}$ was administered $(\mathrm{BUN}=26.0 \pm 0.6$ and

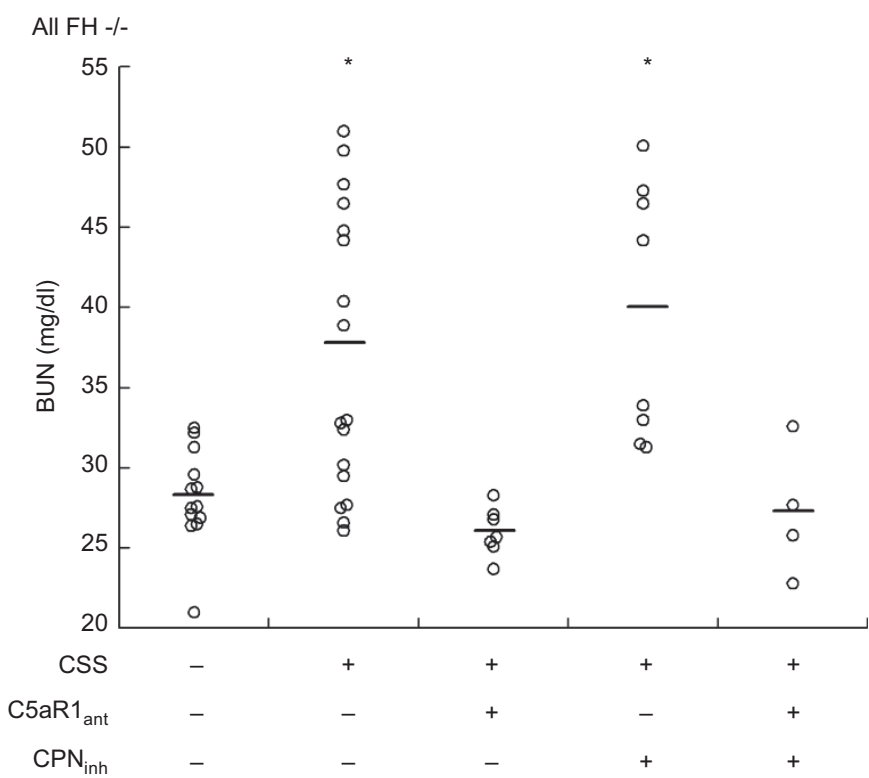

Figure 1 C5a-dependent renal functional impairment in $\mathrm{FH}^{-1-}$ mice with CSS. CSS was induced in $\mathrm{FH}^{-1-}$ mice by daily immunization with apoferritin, or saline alone as control. Groups of animals also received $\mathrm{C}_{5} \mathrm{aR}$ ant and/or $\mathrm{CP}_{\text {inh }}$ after 2 and 3 weeks, respectively. Shown are individual BUN values from all mice studied after 5 weeks. Data from each group were normally distributed. The horizontal lines are the mean value in each group. Groups were significantly different by ANOVA $(P<0.001) .{ }^{*} P<0.02$ versus other three groups.
$27.2 \pm 2.1 \mathrm{mg} / \mathrm{dl}$, respectively). Thus, functional renal insufficiency in the CSS model can be prevented after disease onset by pharmacological blockade of C5aR1.

Histopathological features of ICGN were evaluated at the end of the 5-week experimental protocol (Figure 2). As in past studies ${ }^{18,21}$ a minority (4 of 13) of control $\mathrm{FH}^{-/-}$mice (i.e., without CSS) had some glomerular inflammation with GN

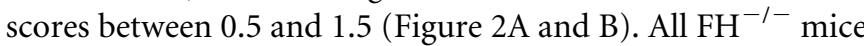
with CSS developed GN with 13 of 17 mice having scores of 1.5 or 2.0 (Figure $2 \mathrm{~A}$ ). The primary histopathological feature was of diffuse hypercellularity of the glomerular tufts (Figure 2C). There was no evidence for thrombotic microangiopathy. As with BUN measurements, mice that received $\mathrm{C} 5 \mathrm{aR} 1_{\text {ant }}$ for the final 3 weeks had significantly less GN (Figure 2D). Here, $\mathrm{CP}_{\text {inh }}$ worsened GN (Figure 2E), including in those mice also receiving $\mathrm{C} 5 \mathrm{aR} 1_{\text {ant }}$. That the extent of GN was related to renal functional impairment is supported by the significant correlation between the two $(\mathrm{BUN}=25.3+(6.0 \times \mathrm{GN}) ; r=0.63, P<$ 0.001 ). Thus, endocapillary diffuse proliferative GN occurring in this model relies upon C5aR1 signaling. These data illustrate that physiological complement regulation by $\mathrm{FH}$ and $\mathrm{CP}$ lessen the amount of $\mathrm{C} 5 \mathrm{a}$ available to bind its receptor in states of IC deposition in glomeruli.

\section{Effects of inhibiting CP on ICGN in wild-type mice}

It appears when plasma $\mathrm{FH}$ is absent in $\mathrm{FH}^{-1-}$ mice with CSS, there is sufficient productive generation of $\mathrm{C} 5 \mathrm{a}$ to signal through $\mathrm{C}_{\mathrm{aR}} 1^{19}$. Given the effects of $\mathrm{CP}_{\text {inh }}$ on $\mathrm{FH}^{-1-}$ mice with CSS, we investigated whether it would affect CSS in wildtype (i.e., $\mathrm{FH}^{+/+}$) mice. All control wild-type mice given saline instead of apoferritin $(n=8)$ had normal BUN values $(<29.0 \mathrm{mg} / \mathrm{dl})$ and no histopathological evidence of GN. Of the mice with CSS, 3 of 5 developed mild GN (score $=0.5$ ) which was reflected by elevated BUN values $(31.5-33.5 \mathrm{mg} / \mathrm{dl}$ ). The mice with CSS also given $\mathrm{CP}_{\text {inh }}$ had a small, but consistent increase in GN, with all five animals having GN scores $0.5-1.0$ and BUN values $\geqslant 33.5 \mathrm{mg} / \mathrm{dl}$ (Figure 3 ). As with $\mathrm{FH}^{-/-}$mice with CSS, GN scores and BUN values were strongly correlated $(\mathrm{BUN}=26.7+(13.1 \times \mathrm{GN}) ; r=0.75, P<0.001)$, supporting the relevance and interrelatedness of these two measures. These data further support the importance of both $\mathrm{FH}$ and $\mathrm{CP}$ to limit C5a generation in pathological states of IC deposition.

\section{Contrasting effects of inhibiting C5aR1 and CP on circulating and glomerular anti-apoferritin IgG} $18, \mathrm{FH}^{-1-}$ mice with CSS had higher sera titers of anti-apoferritin IgG than wild-type $\mathrm{FH}^{+/+}$mice (Figure 4). Interestingly, inhibition of C5aR1 from 3-5 weeks of immunization led to reduction of anti-apoferritin IgG to levels comparable to wildtype mice. Moreover, inhibition of CP led to a significant increase in anti-apoferritin IgG (Figure 4). Thus, production of anti-apoferritin IgG in C57BL/6 mice appears to be fueled by $\mathrm{C} 5 \mathrm{a}-\mathrm{C} 5 \mathrm{aR} 1$ in $\mathrm{FH}^{-1-}$ mice even after the immune response has begun, which can be further increased by inhibiting $\mathrm{CP}$ mediated inactivation of $\mathrm{C} 5 \mathrm{a}$. 

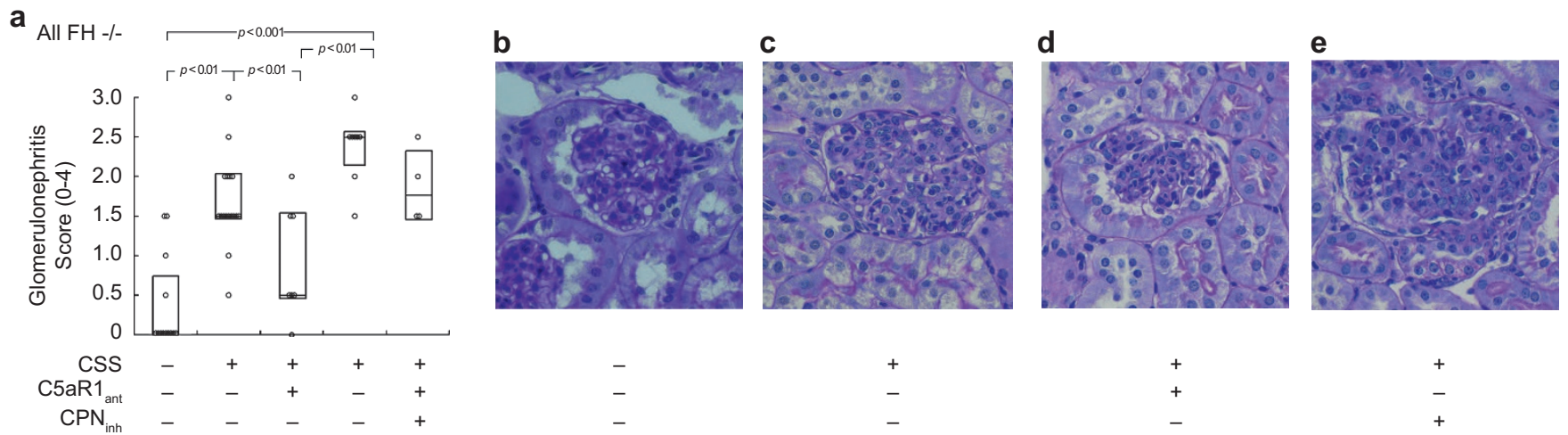

Figure 2 C5a-dependent GN in $\mathrm{FH}^{-1-}$ mice with CSS. CSS was induced in $\mathrm{FH}^{-1-}$ mice by daily immunization with apoferritin, or saline alone as control. Groups of animals also received $\mathrm{C5}_{\mathrm{aR}}$ ant and/or $\mathrm{CP}_{\text {inh }}$ after 2 and 3 weeks, respectively. (A) Individual values of semiquantitative GN scores from all mice studied. The horizontal lines are the median values in each group. The boxes enclose Q1-Q3 intervals. Groups were significantly different by Kruskall-Wallis testing ( $P<0.001$ ), with between-group comparisons shown in the Figure. (B-E) Representative PAS staining of glomeruli from mice from the different groups. Original magnifications, $\times 400$.

Double-label immunofluorescence microscopy was performed to evaluate glomerular IgG and C3 (Figure 5). As shown by the red staining in Figure $5 \mathrm{~B}, \mathrm{FH}^{-1-}$ mice with $\mathrm{CSS}$ had $\mathrm{IgG}$ within mesangial regions (asterisks) with some extension to peripheral capillary walls (arrows). This was reduced in $\mathrm{FH}^{-1-}$ mice with CSS given $\mathrm{C}_{\mathrm{a}} \mathrm{R}_{\text {ant }}$ (Figure $5 \mathrm{C}$ ), and worsened in mice given $\mathrm{CP}_{\text {inh }}$ (Figure 5D). As anticipated, glomeruli from $\mathrm{FH}^{-1-}$ mice had linear glomerular capillary wall staining for C3; this was not appreciably affected by induction of CSS or either of the inhibitors (stained green in Figure 5).

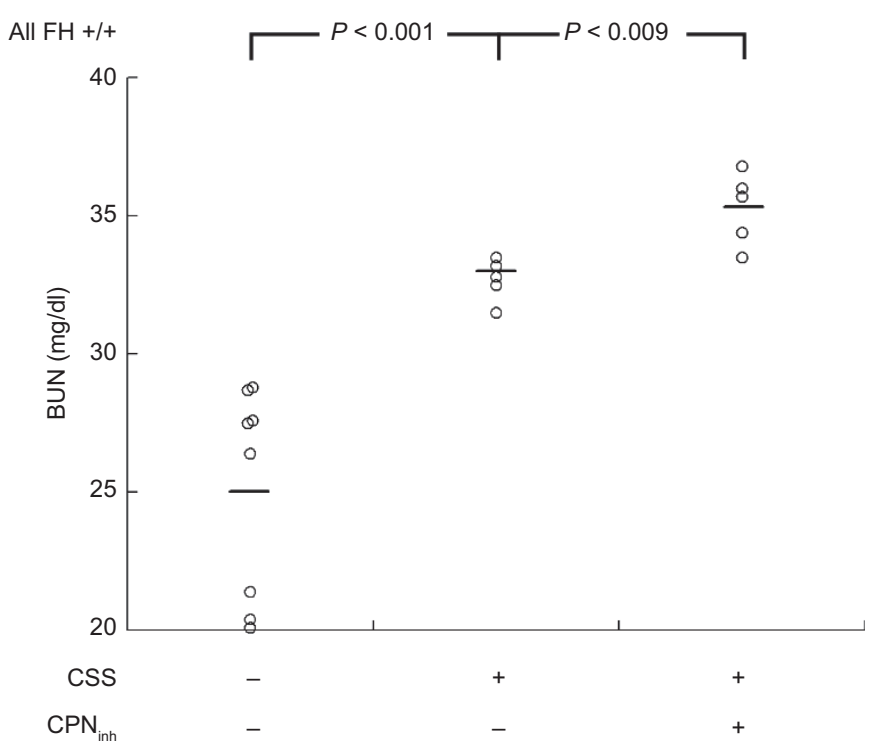

Figure 3 C5a-dependent renal functional impairment in wild-type mice with CSS. CSS was induced in wild-type $\left(\mathrm{FH}^{+/+}\right)$mice by daily immunization with apoferritin, or saline alone as control. One group also received $\mathrm{CP}_{\text {inh }}$ after 3 weeks. Shown are individual BUN values from all mice studied after 5 weeks. Data from each group were normally distributed. The horizontal lines are the mean value in each group. Groups were significantly different by ANOVA $(P<0.001)$. Betweengroup comparisons are depicted in the Figure.

\section{DISCUSSION}

To model IC-mediated GN, we induced CSS through active immunization with heterologous apoferritin as originally described by Stilmant, Couser, and Cotran ${ }^{29}$ and modified by Iskandar et al. ${ }^{31}$ In this model, there is formation of glomerular ICs containing IgG and iC3b; these are ligands for inflammatory cell Fc $\gamma$ Rs and $\beta_{2}$ integrins, respectively. Even in experimental conditions resulting in a large burden of glomerular ICs, C57BL/6 mice with plasma FH have little glomerular inflammation ${ }^{19}$. In contrast, $\mathrm{FH}^{-1-}$ mice are uniformly susceptible to $\mathrm{GN}^{18}$. In the absence of plasma $\mathrm{FH}$, enough $\mathrm{C} 3 \mathrm{~b}$ escapes inactivation to form C5 convertases and generate $\mathrm{C} 5 \mathrm{a}^{19}$. This leads to C5aR1 signals that are required for inflammatory cells to react to glomerular-bound ICs ${ }^{21}$. Here we show mice receiving C $5 \mathrm{aR} 1_{\text {ant }}$ for the final 3 weeks of CSS failed to develop GN and consequent azotemia.

Glomerular disease in CSS was indistinguishable between $\mathrm{FH}^{-1-}$ mice treated with $\mathrm{C} 5 \mathrm{aR} 1_{\text {ant }}$ and wild-type $\mathrm{FH}^{+/+}$mice. Thus, blocking C5aR1 signals "normalizes" $\mathrm{FH}^{-1-}$ mice. Our data allow the conclusion plasma $\mathrm{FH}$ is sufficient to block C5a production below that necessary for GN. Given the large burden of ICs in glomeruli in wild-type mice, we hypothesized some C3b escapes inactivation to facilitate generation of C5a; yet, the efficiency and overlapping nature of normal complement regulation was operative, with $\mathrm{CP}$ inactivating what C5a was generated. We confirmed this by showing treatment with $\mathrm{CP}_{\text {inh }}$ exacerbated disease in wild-type mice. Even in states of considerable C5a generation, such as $\mathrm{FH}^{-1-}$ mice with CSS, CP inactivation of C5a appears to limit disease.

Our accumulated data in CSS illustrate the tight regulation of both innate and adaptive immune systems ${ }^{18,21,22}$. Here we concentrated on the roles of $\mathrm{FH}$ and $\mathrm{CP}$, which show the importance of signaling through $\mathrm{C} 5 \mathrm{aR} 1$ in inflammatory disease. Downstream effects of C5aR1 include increasing Fc $\gamma$ RIII quantities ${ }^{33}$ and $\alpha_{M} \beta_{2}$ integrin (complement receptor 3 ) ligand avidity $^{34,35}$, allowing recognition of, and activation by IgG/ iC3b-bearing ICs in the glomerulus. An elegant paradigm 


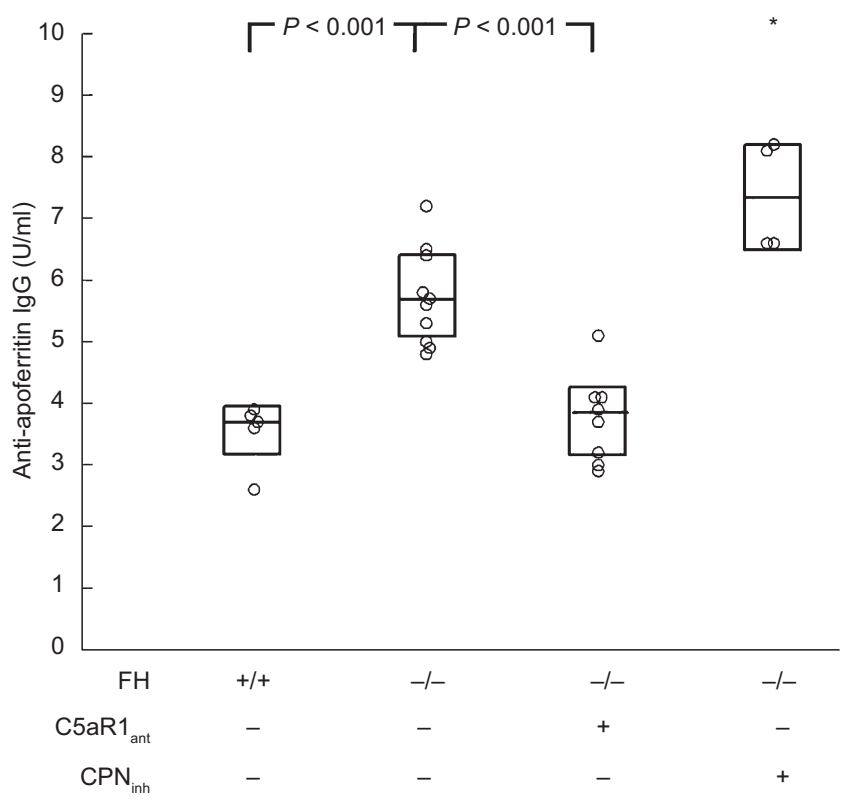

Figure $4 \mathrm{C} 5 \mathrm{a}$ facilitates the humoral immune response in CSS. CSS was induced in wild-type $\left(\mathrm{FH}^{+/+}\right)$mice or $\mathrm{FH}^{-/-}$mice by daily immunization with apoferritin. Groups of animals also received $\mathrm{C} \mathrm{aR}_{\text {ant }}$ or $\mathrm{CP}_{\text {inh }}$ after 2 and 3 weeks, respectively. Shown are individual serum anti-apoferritin IgG values from all mice studied after 5 weeks. Data from each group were not normally distributed. The horizontal lines are the median values in each group. The boxes enclose Q1-Q3 intervals. Groups were significantly different by Kruskall-Wallis testing $(P<0.001)$, with between-group comparisons shown in the Figure. $* P<0.01$ versus other three groups.

advanced and supported experimentally by Gessner et al is C5aR1 activation of $\mathrm{G} \alpha_{\mathrm{i} 2}$ and phosphoinositide 3-kinase p110 $\gamma$ in mononuclear phagocytes leads to a transcriptional increase in Fc $\gamma$ RIII and decrease in Fc $\gamma$ RIIB through respective gene promoter "C5a-inductive" and "C5a-suppressive" regions ${ }^{36-38}$. This phenomenon is relevant in experimental disease models of liver, lung, and kidney (i.e., mesangial cells); ${ }^{38-40}$ clinically relevant is that blocking C5aR1 signals may underlie the therapeutic efficacy of intravenous immunoglobulin ${ }^{41}$. Thus, by altering the balance between activating and inhibitory Fc $\gamma$ Rs on monocytic cells, C5aR1 can have a considerable impact on IC processing and its downstream effects.

We induce the CSS model through repetitive immunization with apoferritin without adjuvant. Animals generate an active anti-apoferritin IgG humoral immune response and deposit IgG in glomeruli, each of which can be quantified. In our prior studies, $\mathrm{FH}^{-1-}$ mice with CSS had increased serum levels of anti-apoferritin IgG compared to wild-type controls, which we attributed to C5aR1 signaling, given equivalent anti-apoferritin IgG titers among wild-type and $\mathrm{FH}^{-1-} \mathrm{C}_{\mathrm{aR}}{ }^{-1-}$ mice ${ }^{21}$. This relationship was true for glomerular IgG as well, which was directly and positively correlated with anti-apoferritin IgG. Interestingly, here we have found comparable findings with pharmacological interventions in the final 3 weeks of the CSS model. That is, inhibiting C5aR1 led to lower serum anti-apoferritin IgG and glomerular IgG, while increasing intact $\mathrm{C} 5 \mathrm{a}$ by blocking its inactivation by $\mathrm{CP}$ increased these two. While these data have been highly consistent relative to $\mathrm{C} 5 \mathrm{a} / \mathrm{C} 5 \mathrm{aR} 1$ and $\mathrm{FH}$, we must emphasize they minimize the intervening steps of IC processing involving plasma $\mathrm{C} 4$ and $\mathrm{C} 3$; erythrocytes bearing CR1 (primates) or platelets bearing FH (rodents); and Fc $\gamma$ RIII and CR3 on mononuclear phagocytes. These are highly complex, as we have found in our studies with this CSS model ${ }^{17,19,21,22,42,43}$. The role for C5aR1 signaling to affect glomerular ICs was supported by studies by Falk and Jennette, in which C5-deficient mice had less glomerular ICs independent from the anti-apoferritin IgG response $\mathrm{e}^{30}$ and by Wenderfer et al. in which C5aR1-deficient MRL/Fas ${ }^{\mathrm{lpr}}$ lupus mice had lower quantities of glomerular ICs compared to C5aR1-sufficient controls ${ }^{44}$

Arguably even more complex than the steps behind IC processing is the generation of a humoral immune response. It has
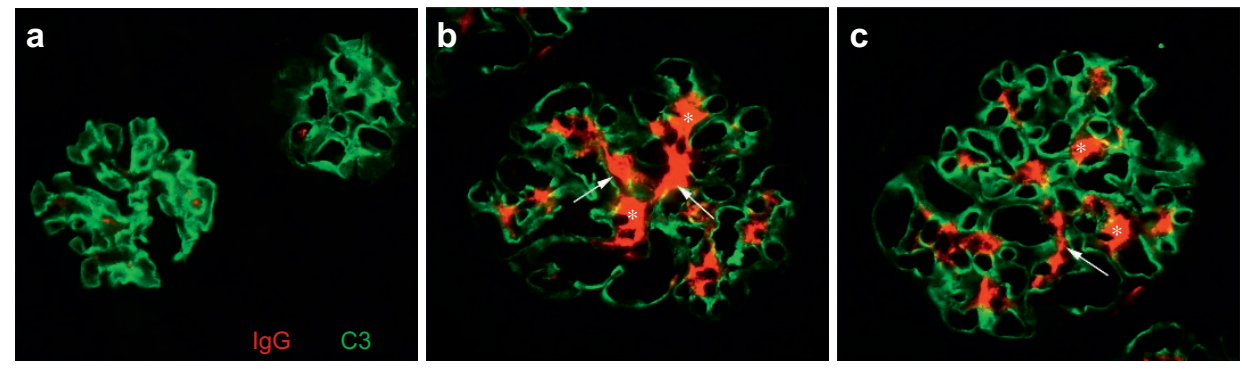

$$
\begin{gathered}
\text { CSS } \\
\mathrm{C}_{\mathrm{aR} 1} 1_{\text {ant }} \\
\mathrm{CPN}_{\text {inh }}
\end{gathered}
$$

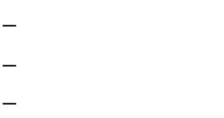

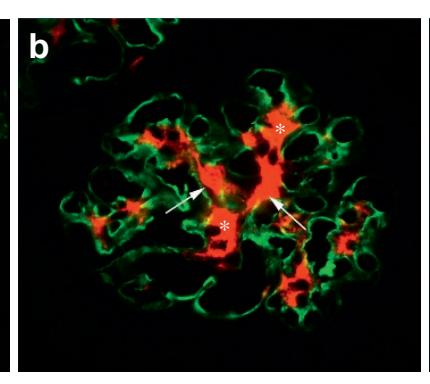

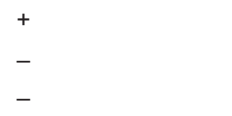

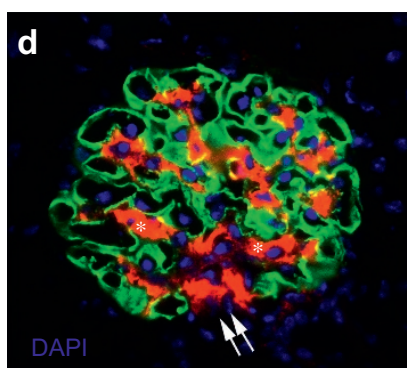

$+$

$-$

Figure 5 C5a enhances glomerular IC deposition in $\mathrm{FH}^{-1-}$ mice with CSS. Representative glomerular immunofluorescence staining for C3 (green) and $\operatorname{lgG}(\mathrm{red})$ is shown for control $\mathrm{FH}^{-1-}$ mice without CSS $(\mathbf{A}), \mathrm{FH}^{-1-}$ mice with CSS $(\mathbf{B})$, and $\mathrm{FH}^{-1-}$ mice with $\mathrm{CSS}$ receiving $\mathrm{C5aR}_{\text {ant }}(\mathbf{C})$ or $\mathrm{CP}$ inh (D). Linear glomerular capillary wall $\mathrm{C} 3$ staining typical for unmanipulated $\mathrm{FH}^{-1-}$ mice was present in all groups. Mesangial lgG was present in all groups with CSS (white asterisks) with some extension to the peripheral capillary walls (white arrows), but in relatively lesser amounts in $\mathrm{FH}^{-1-}$ mice treated with $\mathrm{C5aR}_{\text {ant }}(\mathbf{C})$ and greater amounts in those given $\mathrm{CP}_{\mathrm{inh}}(\mathbf{D})$, in which there was significant extension to peripheral capillary walls (double white arrows). For purposes of localization, nuclei were stained with DAPI (blue) in D. Original magnifications, $\times 400$. 
become clear that $\mathrm{C} 5 \mathrm{aR} 1$ signals are relevant to adaptive immune responses in a variety of ways. From our circumstantial data, there is an anti-inflammatory (M2) macrophage population within the kidney that appears affected by $\mathrm{C} 5 \mathrm{aR} 1^{21}$. In the active humoral immune response, signals through $\mathrm{C} 5 \mathrm{aR} 1$ in both antigen-presenting cells and lymphocytes can promote Th1 and inhibit Treg responses ${ }^{9,10}$.

Perhaps because the glomerular capillary wall contains acellular portions and is exposed to relatively large quantities of plasma proteins, it is particularly at risk of complement activation. In the C3 glomerulopathies, ineffective fluid phase complement regulation allows unrestricted C3 activation and deposition of C3 products in the glomerular capillary wall ${ }^{45-47}$. FH also is retained by the glomerular capillary wall surface; when this is inefficient, endothelial cell injury and atypical hemolytic uremic syndrome can result ${ }^{48-50}$. A comparable pathophysiology is believed to occur in Bruchs membrane in the eye, accounting for the relationship between $\mathrm{FH}$ and age-related macular degeneration ${ }^{51}$.

Pharmacologically targeting the complement system is now clinical reality. Because of the nature of complement activation, many inhibitors directed against a given complement protein also block successive steps in the activation pathway(s). For example, the anti-C5 antibody eculizumab prevents formation of $\mathrm{C} 5 \mathrm{a}$ and C5b-9; the latter accounts for its therapeutic efficacy and now routine clinical use in paroxysmal nocturnal hemolgobinuria, as well as increased risks of Neisserial infections ${ }^{52}$. Eculizumab is highly effective, but it is also the only complement inhibitor in clinical use. Thus, it has been used in a number of past and present clinical trials, including in membranous nephropathy, lupus nephritis, atypical and Shiga-toxin-associated hemolytic uremic syndrome, C3 glomerulopathies, and anti-neutrophil cytoplasmic antigen-associated $\mathrm{GN}^{53-55}$, diseases with a considerable range in phenotype. Identifying which among the limited number of active complement products are pathogenic in a given disease process is not a trivial point. Blocking those not directly relevant to disease will needlessly impair normal immunity as well as potential counterregulatory (anti-inflammatory) signals, for which there is growing evidence ${ }^{3}$.

In summary, here we studied a GN model in which the humoral immune response is directed to a continuously present foreign antigen. It is directly relevant to GN occurring in humans in infectious illnesses (e.g., Streptococcus and Hepatitis C), as well as other IC-mediated GNs such as lupus nephritis, IgA nephropathy, and membranous nephropathy; each of which is characterized by an active humoral immune response, formation of glomerular ICs, and the resulting pathological effects. We show the importance of complement regulation by both plasma $\mathrm{FH}$ and $\mathrm{CP}$ to limit the quantity of active C5a. Signaling through C5aR1 enhances the humoral immune response as well as the inflammatory response to ICs that have formed in glomeruli. Both effects are relevant even after disease has begun. Thus, pharmacological targeting of C5a in IC-mediated GN has potential clinical relevance. This could readily be accomplished by blocking C5 cleavage with eculizumab.

\section{FUNDING SOURCE}

This work was supported by an endowment from Dr Arthur M. Morris, National Institutes of Health grant R01DK041873 to Richard J. Quigg, and by a grant from Kidneeds to Jessy J. Alexander.

1 KIco JM, Nikiforovich GV, Baranski TJ. Genetic analysis of the first and third extracellular loops of the C5a receptor reveals an essential WXFG motif in the first loop. J Biol Chem 2006; 281: 12010-12019.

2 KIco JM, Wiegand CB, Narzinski K, Baranski TJ. Essential role for the second extracellular loop in C5a receptor activation. Nat Struct Mol Biol 2005; 12: 320-326.

3 Sacks S. Complement fragments C3a and C5a: The salt and pepper of the immune response. Eur J Immunol 2010; 40: 668-670.

$4 \mathrm{Klos}$ A, Tenner AJ, Johswich KO, Ager RR, Reis ES, Kohl J. The role of the anaphylatoxins in health and disease. Mol Immunol 2009; 46: 2753-2766.

$5 \mathrm{Klos}$ A, Wende E, Wareham KJ, Monk PN. International Union of Basic and Clinical Pharmacology. [corrected]. LXXXVII. Complement peptide C5a, C4a, and C3a receptors. Pharmacol Rev 2013; 65: 500-543.

6 Roozendaal R, Carroll MC. Complement receptors CD21 and CD35 in humoral immunity. Immunol Rev 2007; 219: 157-166.

7 Peng Q, Li K, Anderson K, Farrar CA, Lu B, Smith RA et al. Local production and activation of complement up-regulates the allostimulatory function of dendritic cells through C3a-C3aR interaction. Blood 2007; 111: 2452-2461.

8 Weaver DJ, Jr., Reis ES, Pandey MK, KohI G, Harris N, Gerard C et al. C5a receptor-deficient dendritic cells promote induction of Treg and Th17 cells. Eur J Immunol 2010; 40: 710-721.

9 Strainic MG, Shevach EM, An F, Lin F, Medof ME. Absence of signaling into $\mathrm{CD} 4(+)$ cells via $\mathrm{C} 3 \mathrm{aR}$ and $\mathrm{C} 5 \mathrm{aR}$ enables autoinductive TGF-betal signaling and induction of Foxp3(+) regulatory T cells. Nat Immunol 2013; 14: 162-171.

10 Kwan WH, van der TW, Paz-Artal E, Li MO, Heeger PS. Signaling through $\mathrm{C} 5$ a receptor and $\mathrm{C} 3$ a receptor diminishes function of murine natural regulatory T cells. J Exp Med 2013; 210: 257268.

11 Heeger PS, Kemper C. Novel roles of complement in T effector cell regulation. Immunobiology 2012; 217: 216-224.

12 Bokisch VA, Muller-Eberhard HJ. Anaphylatoxin inactivator of human plasma: its isolation and characterization as a carboxypeptidase. J Clin Invest 1970; 49: 2427-2436.

13 Nishimura T, Myles T, Piliponsky AM, Kao PN, Berry GJ, Leung LL. Thrombin-activatable procarboxypeptidase $B$ regulates activated complement C5a in vivo. Blood 2007; 109: 1992-1997.

14 Shao Z, Nishimura T, Leung LL, Morser J. Carboxypeptidase B2 deficiency reveals opposite effects of complement C3a and C5a in a murine polymicrobial sepsis model. J Thromb Haemost 2015. doi:10.1111/jth.12956. [Epub ahead of print]

15 Skidgel RA, McGwire GB, Li XY. Membrane anchoring and release of carboxypeptidase $\mathrm{M}$ : implications for extracellular hydrolysis of peptide hormones. Immunopharmacology 1996; 32: 48-52.

16 Skidgel RA, Davis RM, Tan F. Human carboxypeptidase M. Purification and characterization of a membrane-bound carboxypeptidase that cleaves peptide hormones. J Biol Chem 1989; 264: 2236-2241.

17 Quigg RJ, Lim A, Haas M, Alexander JJ, He C, Carroll MC. Immune complex glomerulonephritis in C4- and C3-deficient mice. Kidney Int 1998; 53: 320-330.

18 Alexander JJ, Pickering MC, Haas M, Osawe I, Quigg RJ. Complement factor $\mathrm{H}$ limits immune complex deposition and prevents inflammation and scarring in glomeruli of mice with chronic serum sickness. J Am Soc Nephrol 2005; 16: 52-57. 
19 Alexander JJ, Aneziokoro OGB, Chang A, Hack BK, Markaryan A Jacob $A$ et al. Distinct and separable roles of the complement system in factor $\mathrm{H}$-deficient bone marrow chimeric mice with immune complex disease. J Am Soc Nephrol 2006; 17 1354-1361.

20 Alexander JJ, Wang Y, Chang A, Jacob A, Minto AW, Karmegam M et al. Mouse podocyte complement factor $\mathrm{H}$ - The functional analogue to human complement receptor 1. J Am Soc Nephrol 2007; 18: 11571166.

21 Alexander JJ, Chaves L, Chang A, Quigg RJ. The C5a receptor has a key role in immune complex glomerulonephritis in complement factor H-deficient mice. Kidney Int 2012; 82: 961-968.

22 Alexander JJ, Chaves LD, Chang A, Jacob A, Ritchie M, Quigg RJ. $\mathrm{CD} 11 \mathrm{~b}$ is protective in complement-mediated immune complex glomerulonephritis. Kidney Int 2015. doi:10.1038/ki.2014.373. [Epub ahead of print]

23 Huber-Lang MS, Riedeman NC, Sarma JV, Younkin EM, McGuire SR, Laudes IJ et al. Protection of innate immunity by $\mathrm{C} 5 \mathrm{aR}$ antagonist in septic mice. FASEB J 2002; 16: 1567-1574.

24 Tamamis P, Kieslich CA, Nikiforovich GV, Woodruff TM, Morikis D, Archontis G. Insights into the mechanism of C5aR inhibition by PMX53 via implicit solvent molecular dynamics simulations and docking. BMC Biophys 2014; 7: 5 .

25 Bao L, Osawe I, Puri T, Lambris JD, Haas M, Quigg RJ. C5a promotes development of experimental lupus nephritis which can be blocked with a specific receptor antagonist. Eur J Immunol 2005; 35: 3012-3020.

26 Huey R, Bloor CM, Kawahara MS, Hugli TE. Potentiation of the anaphylatoxins in vivo using an inhibitor of serum carboxypeptidase $\mathrm{N}(\mathrm{SCPN})$. I. Lethality and pathologic effects on pulmonary tissue. Am J Pathol 1983; 112: 48-60.

27 Younger JG, Sasaki N, Waite MD, Murray HN, Saleh EF, Ravage ZB et al. Detrimental effects of complement activation in hemorrhagic shock. J Appl Physiol (1985) 2001; 90: 441-446.

28 Pickering MC, Cook HT, Warren J, Bygrave AE, Moss J, Walport MJ et al. Uncontrolled C3 activation causes membranoproliferative glomerulonephritis in mice deficient in complement factor $\mathrm{H}$. Nat Genet 2002; 31: 424-428.

29 Stilmant MM, Couser WG, Cotran RS. Experimental glomerulonephritis in the mouse associated with mesangial deposition of autologous ferritin immune complexes. Lab Invest 1975; 32: 746-756.

30 Falk RJ, Jennette JC. Immune complex induced glomerular lesions in C5 sufficient and deficient mice. Kidney Int 1986; 30: 678-686.

31 Iskandar SS, Jennette JC, Wilkman AS, Becker RL. Interstrain variations in nephritogenicity of heterologous protein in mice. Lab Invest 1982; 46: 344-351.

32 Passwell J, Schreiner GF, Nonaka M, Beuscher HU, Colten HR. Local extrahepatic expression of complement genes $\mathrm{C} 3$, factor $\mathrm{B}, \mathrm{C} 2$ and $\mathrm{C} 4$ is increased in murine lupus nephritis. J Clin Invest 1988; 82: 16761684.

33 Skokowa J, Ali SR, Felda O, Kumar V, Konrad S, Shushakova N et al. Macrophages induce the inflammatory response in the pulmonary Arthus reaction through $\mathrm{G}$ alpha i2 activation that controls $\mathrm{C} 5 \mathrm{aR}$ and Fc receptor cooperation. $J$ Immunol 2005; 174: 3041-3050.

34 Berger M, Budhu S, Lu E, Li Y, Loike D, Silverstein SC et al. Different G(i)-coupled chemoattractant receptors signal qualitatively different functions in human neutrophils. J Leukoc Biol 2002; 71: 798-806.

$35 \mathrm{Kim}$ M, Carman CV, Springer TA. Bidirectional transmembrane signaling by cytoplasmic domain separation in integrins. Science 2003; 301: 1720-1725.

36 Konrad S, Engling L, Schmidt RE, Gessner JE. Characterization of the murine IgG Fc receptor III and IIB gene promoters: a single twonucleotide difference determines their inverse responsiveness to C5a. J Biol Chem 2007; 282: 37906-37912.

37 Konrad S, Ali SR, Wiege K, Syed SN, Engling L, Piekorz RP et al. Phosphoinositide 3-kinases gamma and delta, linkers of coordinate $\mathrm{C} 5 \mathrm{a}$ receptor-Fcgamma receptor activation and immune complex-induced inflammation. J Biol Chem 2008; 283: 33296-33303.
38 Kumar V, Ali SR, Konrad S, Zwirner J, Verbeek JS, Schmidt RE et al. Cell-derived anaphylatoxins as key mediators of antibody-dependent type II autoimmunity in mice. J Clin Invest 2006; 116: 512-520.

39 Radeke HH, Janssen-Graalfs I, Sowa EN, Chouchakova N, Skokowa J, Loscher $\mathrm{F}$ et al. Opposite regulation of type $\mathrm{II}$ and III receptors for immunoglobulin $\mathrm{G}$ in mouse glomerular mesangial cells and in the induction of anti-glomerular basement membrane (GBM) nephritis. J Biol Chem 2002; 277: 27535-27544.

40 Shushakova N, Skokowa J, Schulman J, Baumann U, Zwirner J, Schmidt RE et al. C5a anaphylatoxin is a major regulator of activating versus inhibitory FcgRs in immune complex-induced lung disease. J Clin Invest 2002; 110: 1823-1830.

41 Konrad S, Baumann U, Schmidt RE, Gessner JE. Intravenous immunoglobulin (IVIG)-mediated neutralisation of C5a: a direct mechanism of IVIG in the maintenance of a high Fc gammaRIIB to FC gammaRIII expression ratio on macrophages. $\mathrm{Br} J$ Haematol 2006; 134: 345-347.

42 Alexander JJ, Hack BK, Cunningham PN, Quigg RJ. A protein with characteristics of factor $\mathrm{H}$ is present on rodent platelets and functions as the immune adherence receptor. J Biol Chem 2001; 276: 3212932135.

43 Alexander JJ, Hack BK, Jacob A, Chang A, Haas M, Finberg RW et al. Abnormal immune complex processing and spontaneous glomerulonephritis in complement factor $\mathrm{H}$-deficient mice with human complement receptor 1 on erythrocytes. J Immunol 2010; 185: 3759-3767.

44 Wenderfer SE, Ke B, Hollmann TJ, Wetsel RA, Lan HY, Braun MC. C5a receptor deficiency attenuates $T$ cell function and renal disease in MRLIpr mice. J Am Soc Nephrol 2005; 16: 3572-3582.

45 Barbour TD, Pickering MC, Cook HT. Recent insights into C3 glomerulopathy. Nephrol Dial Transplant 2013; 28: 1685-1693.

46 Cook HT, Pickering MC. Histopathology of MPGN and C3 glomerulopathies. Nat Rev Nephrol 2015; 11: 14-22.

47 Pickering MC, D'Agati VD, Nester CM, Smith RJ, Haas M, Appel GB et al. C3 glomerulopathy: consensus report. Kidney Int 2013; 84: 1079-1089.

48 Noris M, Caprioli J, Bresin E, Mossali C, Pianetti G, Gamba S et al. Relative role of genetic complement abnormalities in sporadic and familial aHUS and their impact on clinical phenotype. Clin J Am Soc Nephrol 2010; 5: 1844-1859.

49 Zipfel PF, Wolf G, John U, Kentouche K, Skerka C. Novel developments in thrombotic microangiopathies: is there a common link between hemolytic uremic syndrome and thrombotic thrombocytic purpura? Pediatr Nephrol 2011; 26: 1947-1956.

50 Naik A, Sharma S, Quigg RJ. Complement regulation in renal disease models. Semin Nephrol 2013; 33: 575-585.

51 Bradley DT, Zipfel PF, Hughes AE. Complement in age-related macular degeneration: a focus on function. Eye (Lond) 2011; 25: 683-693.

52 Parker C. Eculizumab for paroxysmal nocturnal haemoglobinuria. Lancet 2009; 373: 759-767.

53 Lapeyraque AL, Malina M, Fremeaux-Bacchi V, Boppel T, Kirschfink M, Oualha M et al. Eculizumab in severe Shiga-toxin-associated HUS. N Engl J Med 2011; 364: 2561-2563.

54 Mache CJ, cham-Roschitz B, Fremeaux-Bacchi V, Kirschfink M, Zipfel PF, Roedl $S$ et al. Complement inhibitor eculizumab in atypical hemolytic uremic syndrome. Clin J Am Soc Nephrol 2009; 4: 1312-1316.

55 Salant DJ. Targeting complement $\mathrm{C} 5$ in atypical hemolytic uremic syndrome. J Am Soc Nephrol 2011; 22: 7-9.

This work is licensed under a Creative Commons Attribution 3.0 Unported License. The images or other
third party material in this article are included in the article's Creative Commons license, unless indicated otherwise in the credit line; if the material is not included under the Creative Commons license, users will need to obtain permission from the license holder to reproduce the material. To view a copy of this license, visit http:// creativecommons.org/licenses/by/3.0/ 